DOI:10.2478/v10129-009-0004-8

M. H. Pahlavani ${ }^{1}$, A.A. Miri ${ }^{2}$, G. Kazemi ${ }^{3}$

\footnotetext{
${ }^{1,3}$ Department of Agronomy and Plant Breeding, Gorgan University of Agricultural Sciences, P.O. Box 386, Gorgan, Iran. Iranian Cotton Research Institute, Gorgan, Iran, e-mail: hpahlavani@yahoo.com (Corresponding Author)
}

\title{
RESPONSE OF OIL AND PROTEIN CONTENT TO SEED SIZE IN COTTON(GOSSYPIUM HIRSUTUM L., CV. SAHEL)
}

\begin{abstract}
This study was designed to identify the response of oil and protein content to non-heritable variation of seed size in cotton (Gossypium hirsutum L.). The experiment was conducted at Gorgan University of Agricultural Sciences, Gorgan, Iran in 2005. The results showed that germination and emergence increased linearity with seed size and R2 of these relationships were 92 and $89 \%$, respectively. This means that larger seed had higher potential of germination and emergence. Also, there was a strong linear relationship between seed weight and oil content. Seed weight provided a better indication of oil content $(\mathrm{R} 2=0.78)$ than protein content $(\mathrm{R} 2=0.43)$. There are no considerable relationship between seed size and protein content of seed. The results of this study also showed a positive and significant correlation between seed weight and oil content $\left(\mathrm{r}=0.88^{* *}\right)$, germination percent $\left(\mathrm{r}=0.95^{* *}\right)$, germination index $(\mathrm{r}=0.84 *)$, emergence percent $(\mathrm{r}=0.94 * *)$, and emergence index $\left(\mathrm{r}=0.88^{* *}\right)$. This results suggest that oil content, germination and emergence of cotton seed was largely affected by size of seeds. The effects of seed size where studied here are pure effects of size and is not confounded by other effects such as genotypic factors. This finding helps cotton breeders for the genetic improvement of germination and emergence along with oil and protein content of seeds.
\end{abstract}

Key words: cotton, emergence, germination, oil, seed

\section{INTRODUCTION}

Cotton is currently the leading plant fiber crop, which is grown in over 88 countries with a combined production of 54 million metric tons of cottonseed (Zhu et al. 2005). About two-third of the harvested crop comprises cottonseed which is a potential source of oil, and protein for human and animal consumption. Cottonseed contains $20-40 \%$ of oil, $20-30 \%$ protein, and this level reaches as high as $45-50 \%$ in cotton seed cake after oil extraction. Cottonseed oil commands a higher price in the market than regular vegetable oils because of its higher stability than oils like soybean and canola because it has a very low content of triunsaturated fatty acids, which have a higher tendency to oxidize (Smith and Cothern, 1999). The meal as a high quality protein supplement, have been used successfully and extensively in livestock ration. As the

Communicated by Henryk J. Czembor 
oil and protein content is next to lint in economic importance among the products of the cotton plant, the main objective of cotton improvement is to obtain varieties with high lint and cottonseed. Also, information on the factors influencing content of oil and protein in the cottonseed is of both interest and value to breeders for formulation an appropriate breeding scheme.

The content of oil and protein in cotton as well as other species is associated with the size of the seed that it has a considerable contribution to yield of the crop (Poehlman, 1987). The importance of association between seed size, oil and protein content was showed by others in soybean and mungbean (Marega et al., 2001; Afzal et al., 2003). In addition, seed size plays a major role in germination and establishment of uniform stand of healthy, vigorous seedlings that is essential to achieving high yield. Some researchers showed that in cotton seed size had great influence on the seed germination (Tupper et al., 1971; Bartee and Krieg, 1972; Tupper and Kunz, 1981).) Furthermore, they noted a positive linear relationship between seed weight and emergence in the field. In pea (Pisum sativum L.) it was showed that cultivars with low 100 seed weight had higher laboratory germination percentage than larger seed cultivars (Peken et al., 2004). Baalbaki and Copeland (1997) also concluded that in wheat, seed size not only influence emergence and establishment but also affected yield components and ultimately grain yield. Therefore, knowing regards to response of oil and protein content, seed germination and emergence of seedlings to seed size help cotton researchers to improve the effectiveness of breeding methods.

Cotton is generally considered to be a self-pollinating crop, but it is often cross-pollinated and outcrossing rates are affected by activity of pollinators. Also, the majority of the cotton cultivars are a mixture of closely related genotypes that show plant to plant variation for the all traits especially for seed and seedling growth characteristics (Poehlman, 1987; Smith and Cothern, 1999). On the other hand, indeterminate nature of cotton and extended bloom period, which exposes different seed set to various environmental conditions and field weathering durations, result in different seed qualities and constituents within the same plant. Typically, seed from late-season bolls are usually smaller and less vigorous than seed from earlier bolls (Jenkins et al., 1990a,b). Turner et al. (1979) showed that in cotton as the season progressed weight of seed was more dependent upon environmental factors and fruit load than genetic factors. As a single seed view point, variability of the all limiting factors during development of the seeds, such as nitrogen fertility, water deficit, physiological stresses, and excessive plant populations can considerably impact its final quality in relation to the other seeds. These within-plant variations along with between-plant variation due to cross pollination causes seeds of a particular cultivar had considerable variation in seed traits, especially for seed size (Fasoula and Boerma, 2007).

Although within-cultivar variation of seed size is common; however, the extent to which this variability is effective on seed quality and germination re- 
mains unclear in cotton. Also, in previous work, impact of seed size on quality and germination were evaluated by use of different genotypes, therefore, the pure effects of seed size usually confounded with genotypic effects. So, it is hypothesized that the larger seeds, have grater oil and protein content, and would increase seed germination and emergence in relation to smaller seeds. The present study was designed to test the hypothesis and to investigate the pure effect of seed size on oil and protein content of seeds, and to asses the influence of seed size on the germination and emergence in cotton. The information gained from this experiment may help cotton researchers to recognize suitable size of cottonseed which offer maximum oil and protein content along with high germination and emergence.

\section{MATERIALS AND METHOD}

This study was conducted at the Seed Laboratory, Faculty of Agronomy Sciences, Gorgan University of Agricultural Sciences, Gorgan, Iran in 2005. Seeds of cotton (Gossypium hirsutum L.) cultivar 'Sahel' obtained from Iranian Cotton Research Institute (ICRI) which were grown in 2004 at Research farm of ICRI located at Gorgan, Iran. After ginning with electric gin, delinted seeds were obtained by acid treating with concentrated (commercial) sulphuric acid according to Cross (1962). The acid-delinted seeds were air-dried at room temperature $(25 \pm 1$ şC) on bench tops. The seeds were cleaned manually to remove all foreign matter such as dust, dirt, stones and chaff as well as immature, broken, semi-delinted and fuzzy seeds and stored for 2 months before the start of the experiment. For better understanding of pure effects of size, seeds were separated one by one by hand for weight into size classes of $<00,801-930$, 931-990, 991-1050, 1051-1120, >1121 mg. The mean single seed weight of ungraded sample was $986.7 \mathrm{mg}$ and for the size classes were 740.7, 910.6, $960.6,1018.0,1081.2$ and $1209.6 \mathrm{mg}$, respectively (Table 1). We used from SW1 to SW6 abbreviations for showing 6 seed weight classes in our study.

In spring of 2005, two experiments were carried out. One was conducted in the field for emergence, and another in the laboratory for germination. The experiment carried out in the field used six treatments including seed weight classes (SW1, SW2, SW3, SW4, SW5 and SW6). Each plot was made up of four $3.5 \mathrm{~m}$ rows with $0.4 \mathrm{~m}$ between them and $0.1 \mathrm{~m}$ spacing between seeding. One hundred seeds per each $\mathrm{m}$ of rows were used. Treatments were arranged in a randomized complete block design, with three replications. Emerging seedlings at the soil surface were counted every day for seven after planting and terminated 21 days later in the middle two rows of each plot to determine field emergences percentage. Field emergence percentage (EP) was calculated as the number of emerging seedlings at the last day to the number of planted seeds. Also, emergence index (EI), a measure of the speed of emergence, was calculated by means of data on daily emerging according to the formula developed by Steiner (1990). In the lab experiment, germination test for six weight 
classes were performed according to ISTA rules. Each Petri dish had 50 delinted seeds and experiment run in 4 replications. Similar to field experiment seed germination were recorded daily and germination percentage (GP) and germination index (GI), a measure of the speed of germination, were calculated. Similar to EI, germination index (GI) was calculated by means of data on daily germination according to the formula developed by Steiner (1990).

The oil and protein content of seeds in the each class were determined by Soxhlet and Kjeldahl methods, respectively. The samples for oil and protein content were analyzed in triplicate, and their means was considered in statistical analysis. Nitrogen percentage was multiplied by a constant factor (6.25) for calculating protein content. The oil and protein content were determined according to standard methods of oil and fat analysis (Kaufmann, 1958).

The weight of single seed (SW) and single embryo (EW) and also hull content for all classes was individually determined. Also, dry weight of single embryos was calculated. Since, there was no significant difference between dry weight and fresh weight of embryos, the latter was considered for final statistical analysis. To measure the moisture content (MC) on the basis of dry weight the equation

$$
M C[\%]=\left(\frac{b-a}{a}\right) \times 100
$$

were used for three replications of 100 -seeds sample, where

a was weight $[\mathrm{g}]$ of the same sample after drying in oven at $130 \pm 5^{\circ} \mathrm{C}$ for $2 \mathrm{~h}$ and $b$ was fresh weight $[\mathrm{g}]$ of seed sample.

Also, to determine the percentage water absorption by the seeds, 3 replications of 100 -seed sample were soaked in distilled water at $5 \pm 2^{\circ} \mathrm{C}$ during a $24 \mathrm{~h}$ period. They were extracted from the water and surfaced dried. Water absorption rate (WAR) was calculated using the equation

$$
W A R[\%]=\left(\frac{c-b}{b}\right) \times 100
$$

where c was weight [g] of sample after soaking in distilled water for $24 \mathrm{~h}$.

Linear regression was calculated to determine the relationship between seed weight and others including EW, HC, MC, WAR, GP, GI, EP, EI, oil and protein content (Zar, 1974). Also, Pearson coefficient of correlation among EW, HC, MC, WAR, GP, GI, EP, EI, oil and protein content was determined. All statistical analyses were performed by using SAS procedures: PROC MEANS, PROC REG and PROC CORR (SAS Institute, 1989). 


\section{RESULTS AND DISCUSSION:}

The seed weight of cotton (Gossypium hirsutum L.) cultivar 'Sahel' varied within population by a factor about 6 , from 216 to $1453 \mathrm{mg}$ per seed (data not shown). The mean and standard deviation single seed weight of this population was $986.8 \mathrm{mg}$ and 160.7 , respectively. The observed within cultivar-variation was predictable, because of the indeterminate nature of growth in cotton, in which, there are almost 120 days interval between the first and the last produced seed in each plant (Smith and Cothern, 1999). As shown in Table 1,

Table 1

Mean values \pm standard error of eleven characteristics for six seed weight classes.

\begin{tabular}{lcccccc}
\hline Class & SW $†[\mathrm{mg}]$ & EW $[\mathrm{mg}]$ & Hull [\%] & Oil [\%] & Protein [\%] & MC [\%] \\
\hline SW1 & $740.7 \pm 8.58$ & $466.8 \pm 20.16$ & $36.5 \pm 1.62$ & $17.3 \pm 0.87$ & $23.6 \pm 0.50$ & $9.4 \pm 0.43$ \\
SW2 & $910.6 \pm 0.93$ & $614.3 \pm 6.21$ & $32.5 \pm 0.69$ & $20.9 \pm 0.23$ & $26.5 \pm 1.16$ & $9.3 \pm 0.63$ \\
SW3 & $960.6 \pm 0.92$ & $636.1 \pm 5.70$ & $33.5 \pm 0.53$ & $21.2 \pm 0.43$ & $28.0 \pm 0.87$ & $7.6 \pm 0.74$ \\
SW4 & $1018.0 \pm 0.89$ & $678.5 \pm 3.60$ & $33.1 \pm 0.37$ & $21.6 \pm 0.46$ & $28.9 \pm 0.50$ & $6.6 \pm 0.32$ \\
SW5 & $1081.2 \pm 1.25$ & $727.9 \pm 4.66$ & $32.6 \pm 0.45$ & $21.6 \pm 0.24$ & $28.9 \pm 0.00$ & $6.8 \pm 0.20$ \\
SW6 & $1209.6 \pm 4.11$ & $803.9 \pm 11.23$ & $33.8 \pm 0.47$ & $22.1 \pm 0.17$ & $26.8 \pm 0.58$ & $7.9 \pm 0.98$ \\
\hline Average & 986.8 & 654.6 & 33.7 & 20.8 & 27.1 & 7.9 \\
\hline Class & WAR [\%] & GP [\%] & GI [\%] & EP [\%] & EI [\%] \\
\hline SW1 & $95.0 \pm 1.21$ & $42.5 \pm 5.06$ & $14.5 \pm 2.32$ & $42.6 \pm 8.11$ & $17.1 \pm 3.21$ \\
SW2 & $84.5 \pm 2.20$ & $63.5 \pm 4.64$ & $18.5 \pm 3.29$ & $69.3 \pm 1.76$ & $28.6 \pm 1.67$ \\
SW3 & $84.4 \pm 0.37$ & $68.0 \pm 5.03$ & $22.4 \pm 3.56$ & $68.7 \pm 9.26$ & $29.1 \pm 4.09$ \\
SW4 & $81.4 \pm 0.32$ & $75.5 \pm 5.31$ & $28.9 \pm 3.60$ & $69.3 \pm 3.52$ & $28.3 \pm 0.84$ \\
SW5 & $79.3 \pm 1.40$ & $75.0 \pm 3.69$ & $24.6 \pm 4.42$ & $75.3 \pm 1.76$ & $27.5 \pm 2.60$ \\
SW6 & $79.9 \pm 1.67$ & $82.0 \pm 3.16$ & $26.7 \pm 4.03$ & $83.3 \pm 8.97$ & $34.3 \pm 3.69$ \\
\hline Average & 84.1 & 67.7 & 22.6 & 68.1 & 27.5 \\
\hline SW & & & & \\
\hline
\end{tabular}

SW: single seed weight, EW: single embryo weight, MC: moisture content, WAR: water absorption rate, GP: ermination percentage, GI: germination index, EP: emergence percentage, EI: emergence index

there was considerable variability among six seed weight classes for weight of single embryo (EW), hull, oil and protein content, moisture content (MC), water absorption rate (WAR), germination percentage (GP), germination index (GI), emergence percentage (EP) and emergence index (EI). The highest and lowest values for EW, oil content, GP, EP and EI were belonged to SW1 and SW6, respectively. In average, the classes had $654.6 \mathrm{mg}$ EW, $20.8 \%$ oil, $67.7 \%$ GP, $68.1 \%$ EP and these values could be consider as mean of cotton cultivar Sahel (Table 1). The lowest value for hull, protein, MC, WAR and GI was belonged to SW1 and the highest value of these traits was occurred in SW2, SW5, SW4, SW5 and SW4, respectively. The average value of hull, protein, MC, 

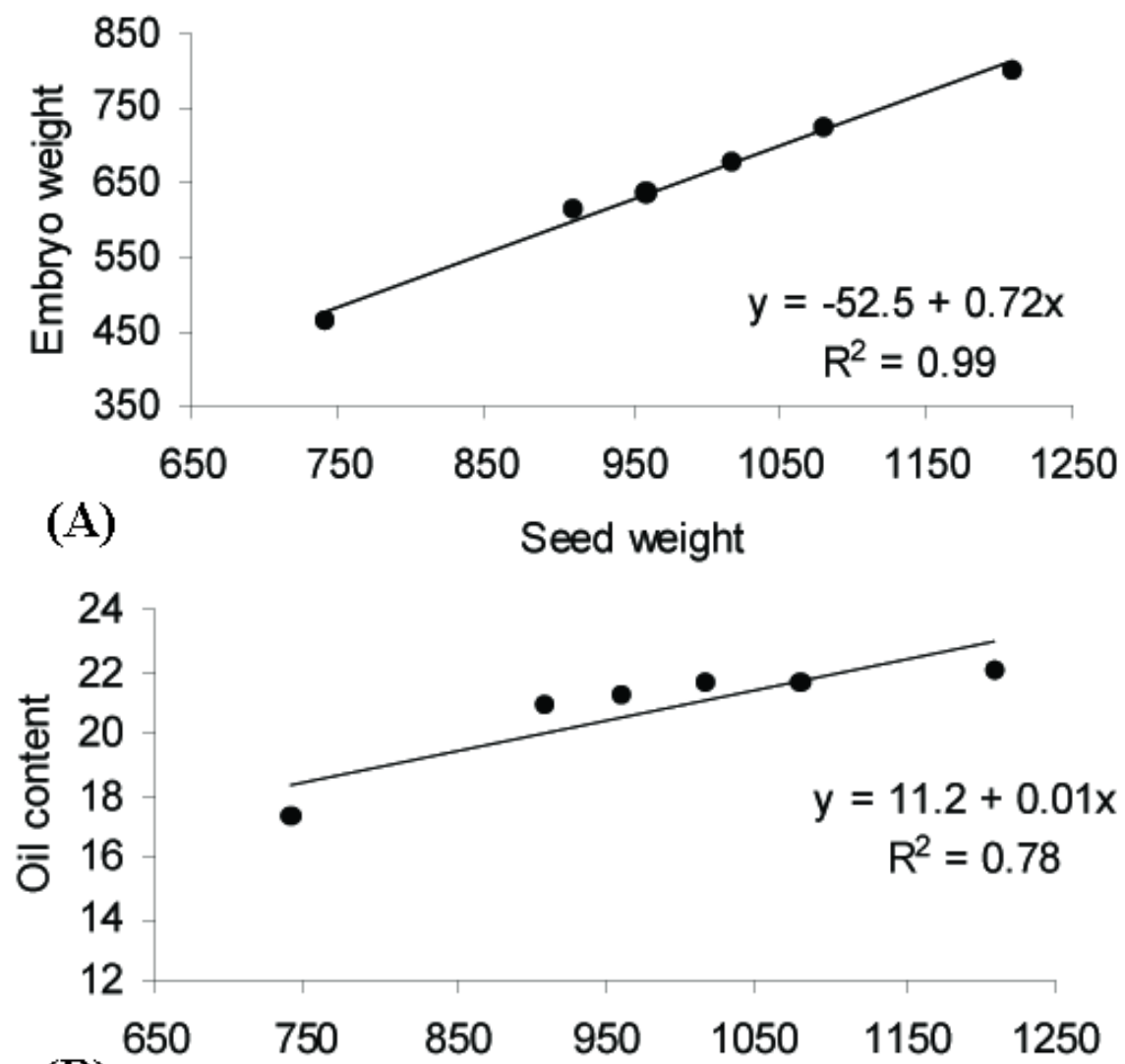
(B)

Seed weight

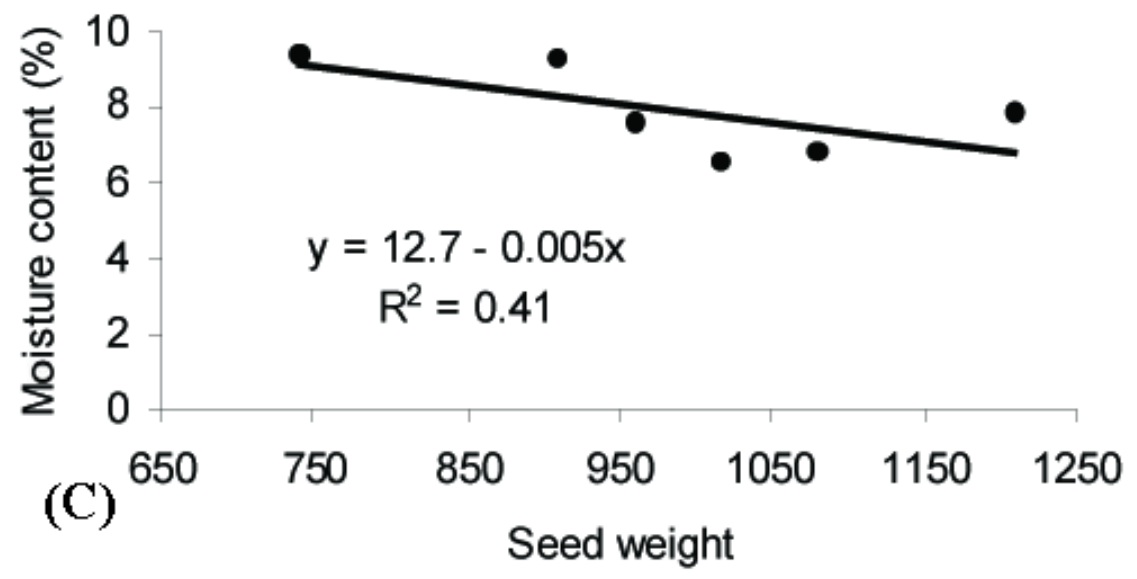

Fig. 1. The relationship between the seed weight and embryo weight (A), oil content (B), and moisture content (C) in cotton cv. Sahel 

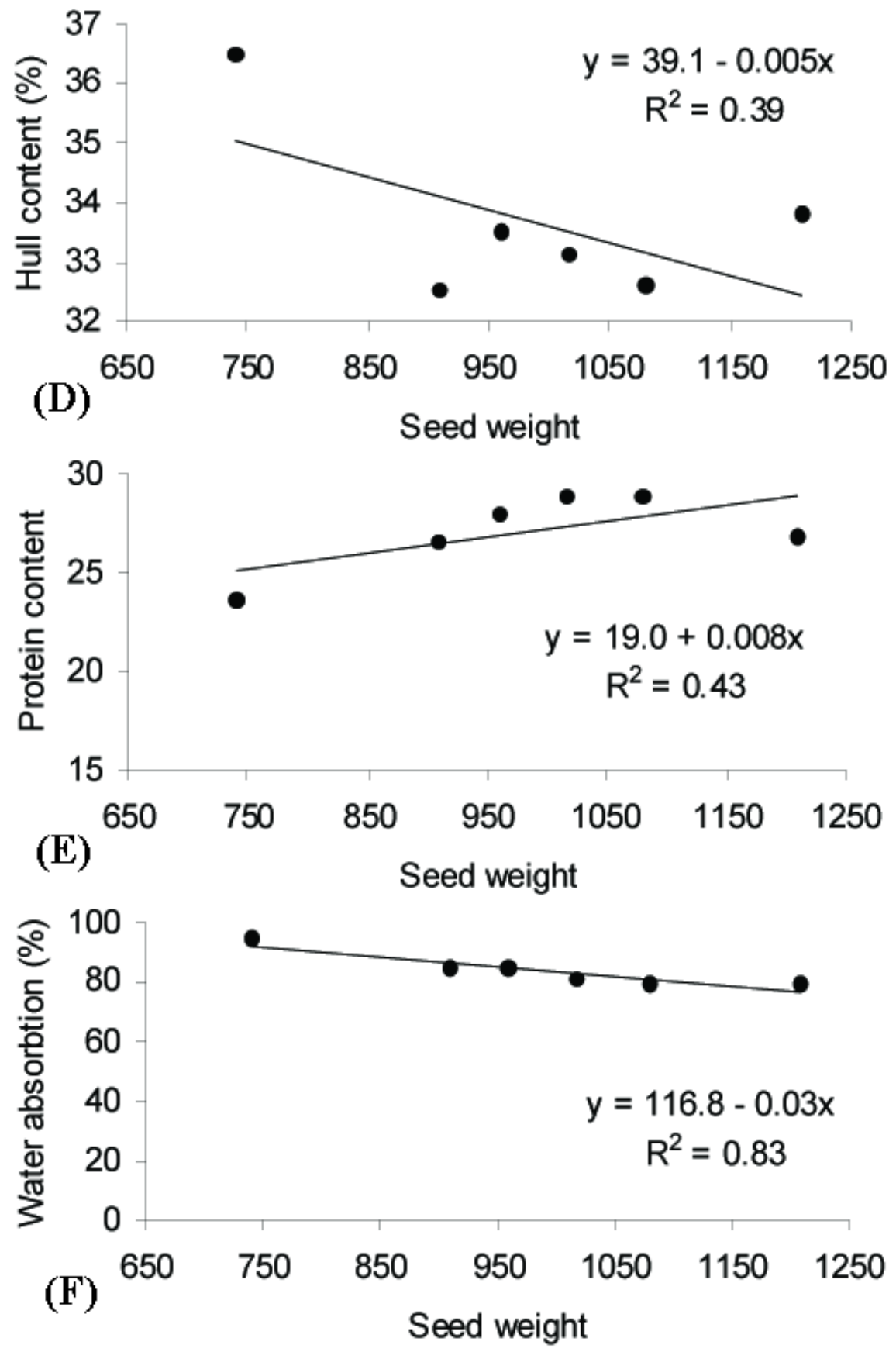

Fig. 1. The relationship between the seed weight and hull content (D) protein content (E) and water absorption $(\mathrm{F})$ in cotton cv. Sahel 


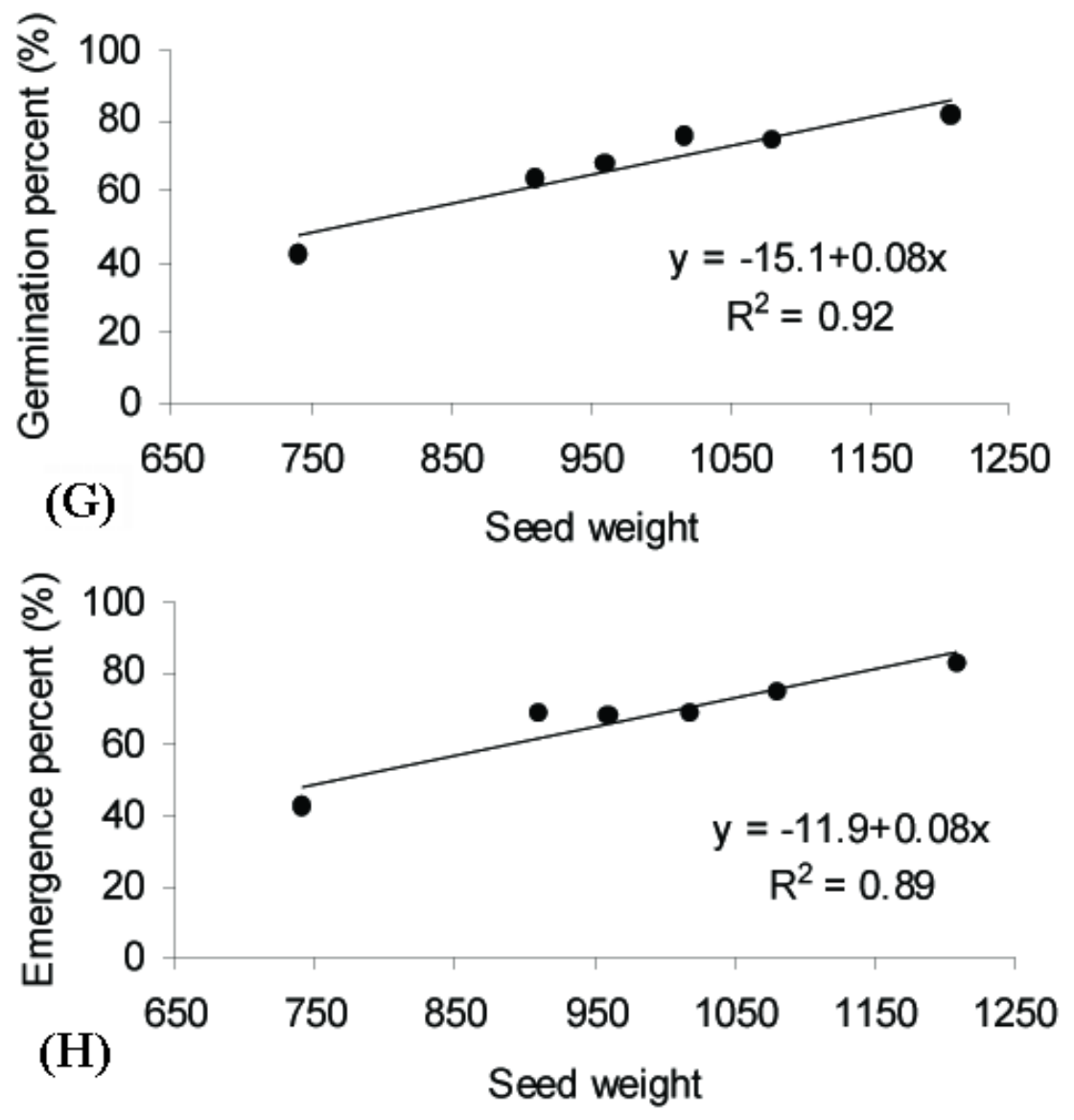

Fig. 1. The relationship between the seed weight and germination percent (G) and emergence percent $(\mathrm{H})$ in cotton $\mathrm{cv}$. Sahel

WAR and GI in all classes was 33.7\%, 27.1\%, 7.9\%, 84.1 and $22.6 \%$, respectively (Table 1). The mean of oil and protein content that observed in this study were similar to those reported by others in cotton (Lukonge et al., 2006). The content of oil in cotton seeds increased from 17.3 in SW1 (seed size class) to $22.1 \%$ in SW6. A similar trend was observed for seed growth related parameters including GP, GI, EP and EI, and improvement order was SW1 $<$ SW2 < SW3 $<$ SW4 $<$ SW5 $<$ SW6 (Table 1). A similar observation was made by Cornish and Hindmarsh (1988) while working with two cultivar of wheat, Triticum aestivum $\mathrm{L}$. and they concluded that this was attributed to the larger food reserves in the larger seeds.

Embryo weight increased as the seed weight increased $(\mathrm{R} 2=0.99)$. There was a strong linear relationship between seed weight and oil content (Fig. 1). Regression analysis indicated that a 1.0 unit increase in the seed weight improved oil content 0.01 (Fig. 1). Also, seed weight provided a better indication of oil 

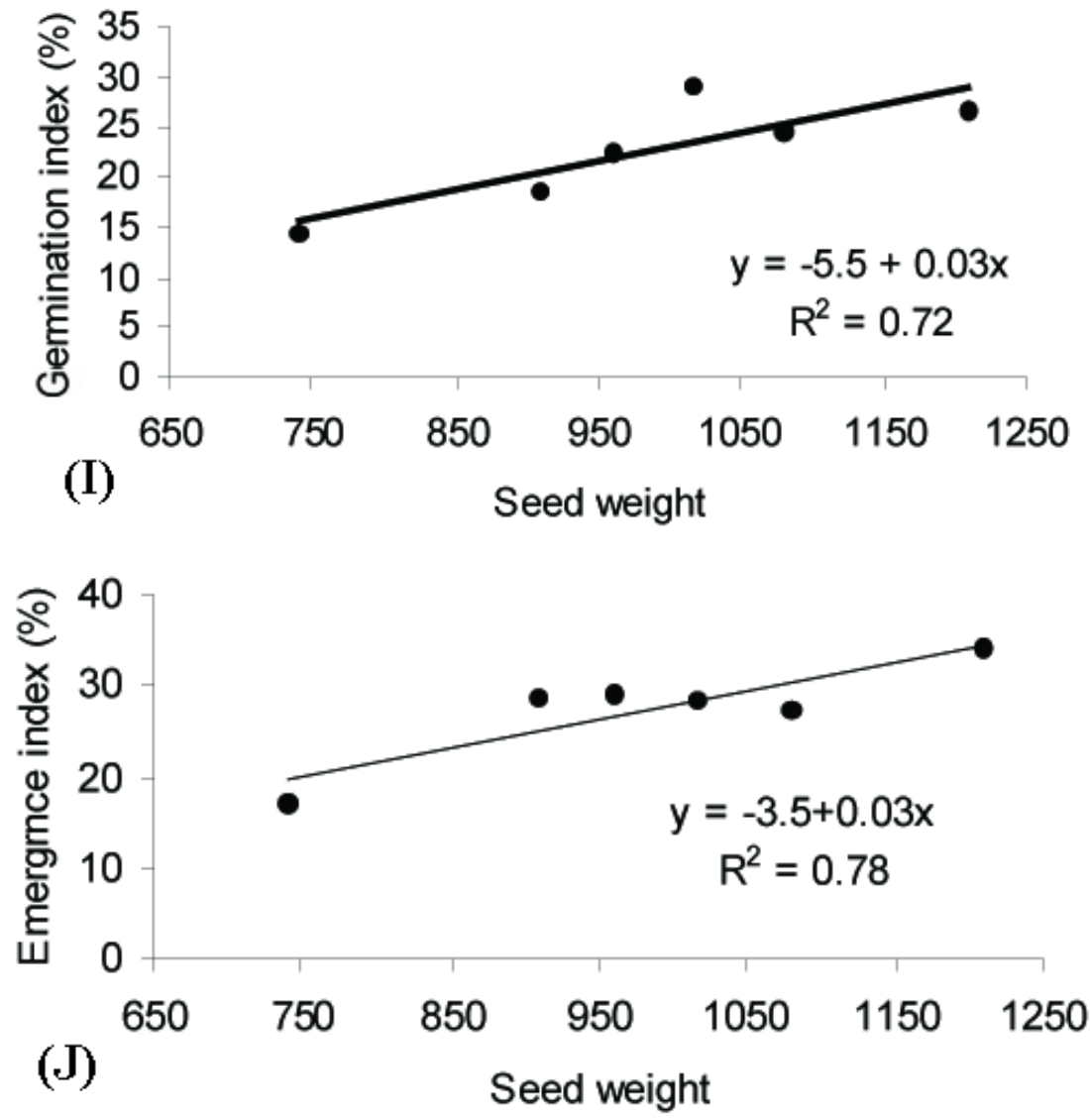

Fig. 1. The relationship between the seed weight and germination index (I) and emergence index $(J)$ in cotton $\mathrm{cv}$. Sahel

content $(\mathrm{R} 2=0.78)$ than protein content $(\mathrm{R} 2=0.43)$. Marega et al. (2001) showed that at the field experiment, the combined analysis showed a high significant relationship between weight of a hundred seed and oil content. Similar results were obtained by Chaudhy and Ikram (2001) in maize where seed size had no significant effect on protein content. The results of regression analysis also showed that increasing of seed weight decreased moisture content $(\mathrm{R} 2=0.41)$ and water absorption $(\mathrm{R} 2=0.83)$ over six seed weight classes.

Seeds with a lower weight (SW1 and SW2) had higher moisture content; whereas those of higher seed weight (SW4 and SW5) had lower moisture content (Fig. 1). Seed moisture can have the largest effect on seed quality throughout the production, ginning, storage, delinting and conditioning processes. Ideally, seed should be dry and harvesting should only occur when seed moisture content is less than $12 \%$. 
Germination percent (GP), germination index (GI), emergence percent (EP) and emergence index (EI) increased linearity with seed size and coefficient of determination (R2) of theses relationship were $0.92,0.72,0.89$ and 0.78 , respectively (Fig. 1). Tupper et al. (1971) and Tupper and Kunz (1981) reported that seed size is the physical characteristics that had greatest influence on the germination of cotton (from Smith p. 305). Bartee and Krieg (1972) also reported that seed size was directly correlated to percent germination. Furthermore, they noted in the field a positive linear relationship between seed size and emergence (from smith p.306). A similar observation was made by Arunachalam et al. (2003) while working with the tree species, and this was attributed to the larger food reserves in the larger seeds. These results also are in conformity with Singh and Singh (2003) in wheat. Also, these results indicated that seed size had greater effect on percent than index of germination and emergence (Fig. 1).

Phenotypic correlations among the eleven seed related traits in Cotton cv. Sahel $(n=6)$

\begin{tabular}{|c|c|c|c|c|c|c|c|c|c|c|}
\hline & $\begin{array}{c}\text { EW } \\
{[\mathrm{mg}]}\end{array}$ & $\begin{array}{l}\text { Hull } \\
{[\%]}\end{array}$ & $\begin{array}{l}\mathrm{MC} \\
{[\%]}\end{array}$ & $\begin{array}{c}\text { WAR } \\
{[\%]}\end{array}$ & $\begin{array}{c}\text { Oil } \\
{[\%]}\end{array}$ & $\begin{array}{c}\text { Protein } \\
{[\%]}\end{array}$ & $\begin{array}{c}\text { GP } \\
{[\%]}\end{array}$ & $\begin{array}{c}\mathrm{GI} \\
{[\%]}\end{array}$ & $\begin{array}{c}\mathrm{EP} \\
{[\%]}\end{array}$ & $\begin{array}{c}\text { EI } \\
{[\%]}\end{array}$ \\
\hline $\mathrm{SW}[\mathrm{mg}]$ & $0.99 * *$ & -0.58 & -0.64 & $-0.91 * *$ & $0.88^{* *}$ & 0.65 & $0.95 * *$ & $0.84^{*}$ & $0.94 * *$ & $0.88^{* *}$ \\
\hline EW [mg] & 1 & -0.65 & -0.64 & $-0.94 * *$ & $0.91^{* *}$ & 0.69 & $0.97^{* *}$ & $0.84^{*}$ & $0.94 * *$ & $0.88^{* *}$ \\
\hline Hull [\%] & & 1 & 0.52 & $0.85^{*}$ & $-0.86^{*}$ & $-0.83^{*}$ & -0.74 & -0.59 & $-0.79^{*}$ & -0.73 \\
\hline $\mathrm{MC}[\%]$ & & & 1 & 0.74 & -0.67 & $-0.89 * *$ & -0.74 & $-0.87 *$ & -0.56 & -0.46 \\
\hline WAR [\%] & & & & 1 & $-0.97 * *$ & $-0.87^{*}$ & $-0.97 * *$ & $-0.86^{*}$ & $-0.96^{* *}$ & $-0.87^{*}$ \\
\hline Oil [\%] & & & & & 1 & $0.87^{*}$ & $0.97 * *$ & $0.85^{*}$ & $0.97 * *$ & $0.94 * *$ \\
\hline Protein [\%] & & & & & & 1 & $0.81^{*}$ & $0.82 *$ & 0.72 & 0.65 \\
\hline GP [\%] & & & & & & & 1 & $0.92 * *$ & $0.96^{* *}$ & $0.92 * *$ \\
\hline GI [\%] & & & & & & & & 1 & 0.78 & 0.71 \\
\hline EP [\%] & & & & & & & & & 1 & $0.96^{* *}$ \\
\hline EI [\%] & & & & & & & & & & 1 \\
\hline
\end{tabular}

* and ** significant at 5 and $1 \%$, respectively.

SW: single seed weight, EW: single embryo weight, MC: moisture content, WAR: water absorption rate, GP: germination percentage, GI: germination index, EP: emergence percentage, EI: emergence index

As shown in Table 2, positive and significant correlation was found between seed weight with oil content $\left(\mathrm{r}=0.88^{* *}\right)$, germination percent $\left(\mathrm{r}=0.95^{* *}\right)$, germination index $(\mathrm{r}=0.84 *)$, emergence percent $(\mathrm{r}=0.94 * *)$, and emergence in$\operatorname{dex}\left(\mathrm{r}=0.88^{* *}\right)$ (Table 2$)$. This means that larger seed had higher potential of germination and emergence as described by Smart and Moser (1999) in switchgrass and Hopper et al. (1979) in soybean. Amico et al., (1994) also concluded that higher vigor that occurred in larger seed is due to the larger food re- 
serves in these seeds. Association between seed size and oil content previously reported in soybean (Marega et al., 2001).

As expected, significant and negative correlation was observed between water absorption rate with GP $(\mathrm{r}=-0.97 * *)$, GI $\left(\mathrm{r}=-0.86^{*}\right)$, EP $\left(\mathrm{r}=-0.96^{* *}\right)$ and EI $\left(\mathrm{r}=-0.87^{*}\right)$ (Table 2$)$. In the other word, larger seed had higher ability of water absorption in relation to smaller them. These results are in conformity with Reddy et al. (1980). Positive and significant association was observed between GP with GI $\left(\mathrm{r}=0.82^{*}\right)$ and also between EP and EI $\left(\mathrm{r}=0.96^{* *}\right)$ (Table 2$)$. These results indicated that total germination/emergence of a seed lot is related to the speed with which seeds germinate/emerge, respectively. Thus a seed lot exhibiting uniform and rapid germination/mergence should also have a high total germination/emergence. Such positive correlations have been reported in cotton (Pahlavani, 1999) and other species, including sunflower (Ahmad, 2001) and soybean (Adkins, et al., 1996).

\section{CONCLUSION}

Seed size that usually evaluated by seed weight is affecting by numerous heritable and environmental factors. In the other hand changes in seed size could directly differ oil content of the seeds especially in indeterminate plants such cotton which are considerably under effects of environmental factors. Also, differences in seed size in the present study are completely due to non-heritable factors. Therefore, it could be concluded that effects of seed size where studied here are pure effects of size and is not confounded by other effects such as genotypic factors which is common in these studies that previously performed. Overall, results of this study showed that oil content, germination and emergence of cotton seed was largely affected by size of seeds. This findings helps cotton breeders that commonly, does not look for the genetic improvement of isolated traits, but for the genetic improvement of a set of traits, since, it is interesting for the breeder to know the intervention in one trait can cause alteration in others.

\section{REFERENCES}

Adkins S.W., Boersma M. and M Law, 1996. Relationship between vigour tests and emergence of soybean when grown under a range of seedbed moisture conditions, Australian Journal of Experimental Agriculture 36: 93-97.

Afzal M.A., Bashir M.M., Luna N.K., Bakr M.A., and M. M. Haque, 2003. Relationship between seed size, protein content and cooking time of Mungbean [Vigna radiata (L.) Wilczek] Seeds, Asian Journal of Plant Sciences 2: 1008-1009.

Ahmad S., 2001.Environmental Effects on Seed Characteristics of Sunflower (Helianthus annuus L.), Journal of Agronomy and Crop Science, 187: 213-216.

Amico R.U., Zizzo, G.V., Agnello, S., Sciortino, A. and Iapichino, G. 1994. Effect of seed storage and seed size on germination, emergence and bulbelt production of Amaryllis belladonnal L., Acta Hort. (ISHS) 362: $281-288$.

Baalbaki R.Z. and L.O. Copeland 1997. Seed size, density and protein content effect on field performance of wheat, Seed Science and Technology, 25: 511-521.

Bartee S.N and D.R. Krieg, 1972. Influence of density on cottonseed germination, emergence and chemical composition, Proc. Beltwide Cotton Prod. Conf. 1981: 306-308. 
Cross, J.E. 1962. An improved method of acid-treating small quantities of cotton seed. Empire Cotton Growing Review. 39: 205.

Fasoula V.A. and H.R. Boerma 2007. Intra-Cultivar Variation for Seed Weight and Other Agronomic Traits within Three Elite Soybean Cultivars. Crop Sci 47: 367-373.

Hopper N.W., J.R. Overholt and J.R. Martin 1979. Effect of Cultivar, Temperature and Seed Size on the Germination and Emergence of Soya Beans (Glycine max (L.) Merr.), Annals of Botany 44: 301-308.

Jenkins, J.N., J.C. McCarty, and W.L. Parrot. 1990a. Effectiveness of fruiting sites in cotton: Yield. Crop Sci. 30: 365-369.

Jenkins, J.N., J.C. McCarty, and W.L. Parrot. 1990b. Fruiting efficiency in cotton: Boll size and boll set percentage. Crop Sci. 30: 857-860.

Kaufmann, H.P. 1958. Analyse der fette and fettprodukte. Springer Verlag, Berlin. 360p.

Lukonge E., M.T. Labuschagne and A. Hugo, 2006. The evaluation of oil and fatty acid composition in seed of cotton accessions from various countries, Journal of the Science of Food and Agriculture, 87: 340-347.

Marega M. F., D. Destro, L. A. Miranda, W. A. Spinosa, M. C. Carrao-Panizzi and R. Montalvan 2001. Relationship among oil content, protein content and seed size in soybeans. Brazilian Archives of Biology and Biotechnology. 44: 23-32.

Pahlavani, M.H. 1999. Evaluation of quantitative and qualitative charactrestics of cotton (Gossypium hirsutum L.) cultivars in nonirigated and nonirigated with complementary water supply conditions, M.Sc. Thesis, Univ. Isfahan Technilogy, Iran, 109p.

Pekoen E., Pekoen A., Bozotmlu H. and A. Gülümser 2004. Some Seed Traits and Their Relationships to Seed Germination and Field Emergence in (Pisum sativum L.). Journal of Agronomy, 3: 243-246.

Poehlman J.M. 1987. Breeding Field Crops. AVI Publishing Company Inc., New York. 724p.

SAS Institute 1989. SAS/STAT User's Guide, Version 6.4th, ed. SAS Inst., Cary, NC.

Singh and Singh. 2003. Seed size and adventitious (nodal) roots as factors influencing the tolerance of wheat to waterlogging, Australian Journal of Agricultural Research, 54 (10), 969-977.

Smart A.J. and L.E. Moser 1999. Switchgrass seedling development as affected by seed size. Agron. J. 91:335-338.

Smith C. M. and J. T. Cothern 1999. Cotton, Origin, History, Technology and Production. John Wiley \& Sons, Inc. $850 \mathrm{p}$.

Steiner j.j. 1990. Seedling rate of development index: indicator of vigor and seedling growth response. Crop Sci., 30: 1264-1271.

Tupper G.R., O.R. Kunze, 1981. Relation of seed density and weight to seed quality: Culling by liquid separation, Proc. Beltwide Cotton Prod. Conf. 1981: 306-308.

Tupper G.R., O.R. Kunze and L.H. Wilkes, 1971. Physical characteristics of cottonseed related to seedling vigor and design parameters for seed selection. Trans ASAE, 14: 890-893.

Turner J.H., S. Worley, H.H. Ramey, P.E. Hoskinson and J.M. Stewart 1979. Relationship of week of flowering and parameters of boll yield in cotton, Agron J. 71: 248-251.

Zhu S. J., N. Reddy and Y. R. Jiang 2005. Introgression of a gene for delayed pigment gland morphogenesis from Gossypium bickii into upland cotton, Plant Breeding 124: 590-594. 